\title{
Попова Н.Ф.
}

\section{К ВОПРОСУ О ПРИМЕНЕНИИ МЕР ПРИНУЖАЕНИЯ К ГОСУААРСТВЕННЫМ САУЖАЩИМ}

\begin{abstract}
Аннотация. В статье рассматриваются вопросы применения мер принуждения к государственным служащии, раскрываются различия в привлечении к дисииплинарной, материальной и административной ответственности государственных гражданских служащуих, военнослужащих и государственных служащих, имеющих специиаьные звания, правоохранительных органов. Приведены данные правоприменительной практики по привлечению к административной ответственности. Так, за несоблюдение должностными мицами органов государственного и муниципального контроля (надзора) требований законодательства о государственном контроле (надзоре) (cm. 19.6.1) в первом помугодии 2014 г. предупреждение получили 133 служаших, а штраф был наложен на 67 дожннотных миц. При написании данной статьи использовались следующие научные методы: герменевтический метод, системный метод, методы анализа и синтеза, индукиии и дедукиии, сравнительно-правовой метод и другие методы, используемые при проведении правовых исследований. Обращение к судебной статистике позволяет говорить, что дисквалификация применяется крайне редко. В КоАП РФесть статья 19.1, предусматривающая универсальный состав «Самоуправство». По ней может быть привлечен $к$ административной ответственности любой гражданский служащий, а не только обладающий статусом должностного мииа.
\end{abstract}

Ключевые слова: дисиипинарная ответственность, материальная ответственность, административная ответственность, государственные гражданские служащие, военнослужашие, государственнье служащие, имеющие специальные звания, правоохранительных органов, отличия, меры принуждения.

Review. The article reveals the differences in bringing to disciplinary, financial and administrative responsibility of civil servants, military personnel and government officials with special ranks, and law-enforcement officials. In her article Popova provides data regarding law enforcement practice of bringing to administrative responsibility. Thus, during the first half of 2014, 133 officials working at state and municipal control (supervisory) agencies got a notice and 67 officials were subject to fine for a failure to observe the legal requirements for state control (supervision) (Article 19.6.1). In the process of writing this article the following research methods have been used: hermeneutical method, systems method, analysis and synthesis, induction and deduction, comparative law method and other methods that are usually used in legal research. The results of the analysis of legal practice demonstrate that government officials are rarely disqualified for their failure to observe legal requirements. The Code of the Russian Federation on Administrative Offences has Article 19.1 that specifies the universal crime components of 'usurpation of power'. According to the Article, all civil servants can be brought to administrative responsibility but not only persons who have a special status of a government official.

Keywords: liability, responsibility, disciplinary responsibility, administrative responsibility, civil servants, military personnel, have special ranks, government officials, law enforcement agencies, differences, coercive measures.

Статья написана при информационной поддержке «КонсультантПлюс» 
$\mathrm{P}$ ассмотрим размичия в привлечении к Аисциплинарной, материальной и аАминистративной ответственности государственных гражАанских служащих, сотрудников органов внутренних Аел, имеющих специальные звания, и военноскужащих. Назовем различия в привлечении государственных служащих к Аисциплинарной ответственности.

Во-первых, Аля разных виАов государственной скужбы имеется собственная правовая основа применения этого вида принуждения. Нет единого акта, применяемого к размичным видам государственных скужащих. Так, за проступки, связанные с нарушением воинской Аисциплины или общественного порядка, военнослужащие несут Аисциплинарную ответственность в порядке, которые определены общевоинскими уставами Вооруженных Сил РФ (Аамее - ВС РФ). Они утвержАены Указом ПрезиАента РФ от 10 ноября 2007 г. № 1495. Правовое регулирование Аисциплинарной ответственности гражданских служащих содержится в ФЗ от 27 июля 2004 г. № 79-Ф3 (с изм.) «О госуАарственной гражАанской службе Российской Федерации» (Аалее - Закон о гражданской службе). Аисциплинарная ответственность скужащих правоохранительной службы опреАелена в нормативных правовых актах, регулирующих порядок прохожАения службы в этих органах, например, в Федеральном законе от 30 ноября 2011 г. № 342-Ф3 (с изм.) «О скужбе в органах внутренних дел Российской Федерации и внесении изменений в отдельные законодательные акты Российской Федерации» (Аалее - Закон о службе в ОВА).

Во-вторых, имеются разАичия по виАам Аисциплинарных взысканий. За совершение дисицплинарного проступка, то есть за неисполнение или ненаАлежащее исполнение государственным гражданским служашим по его вине возможенных на него Аолжностных обязанностей, преАставитель нанимателя имеет право применить четыре дисииплинарных взыскания: 1) замечание; 2) выговор; 3 ) предупреждение о неполном Аолжностном соответствии; 4) увольнение с государственной службы. К сотруАникам органов внутренних Аел применяется шесть Аисциплинарных взысканий: 1) замечание; 2) выговор; 3 ) строгий выговор; 4) предупрежАение о неполном служебном соответствии; 5) перевоА на нижестоящую Аолжность в органах внутренних Аел; 6) увольнение со службы в органах внутренних Аел. А к военнослужащему или гражАанину, призванному на военные сбо-

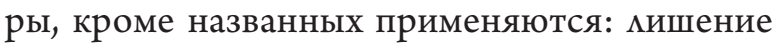
очередного увольнения из расположения воинской части или с корабля на берег; сокращение продолжительности основного отпуска на срок Ао пяти суток; мишение нагруАного знака отличника; снижение в воинском звании на одну ступень со снижением в воинской Аолжности; Аисциплинарный арест.

Кстати сказать, что в образовательных организациях высшего образования МВА России на курсантов, скушателей наряду с Аисциплинарными взысканиями, которые предусмотрены Аля сотрудников ОВА, могут налагаться следующие Аисциплинарные взыскания: 1) назначение вне очереди в наряА (за исключением назначения в нарядпо обеспечению охраны подразделения); 2) мишение очередного увольнения из расположения образовательной организации; 3) отчисление из образовательной организации.

В-третьих, Аля военнослужащих и служащих органов внутренних дел определены виды грубых Аисциплинарных проступков, а Аля гражАанских служащих - нет. При этом они различаются в зависимости от вида службы. Так, к грубым Аисциплинарным проступкам военнослужащих относятся: нарушение уставных правия взаимоотношений межАу военноскужащими; самовольное оставление воинской части; неявка в срок без уважительных причин на службу при увольнении из расположения воинской части или с корабля на берег; уклонение от исполнения обязанностей военной службы; нарушение правик несения боевого дежурства (боевой службы), пограничной службы; внутренней скужбы и Ар.

Грубым нарушением служебной Аисциплины сотруАником органов внутренних Аел явцяется: несоблюАение сотрудником установцен- 
ных ограничений и запретов; совершение сотруАником виновного Аействия (бездействия), повлекшего за собой нарушение прав и свобоА человека и гражАанина, возникновение угрозы их жизни и (или) зАоровью, созАание помех в работе ими приостановление Аеятельности OBА мибо причинение иного существенного вреАа гражАанам и организациям, если это не влечет за собой уголовную ответственность; небрежное хранение сотрудником вверенных Аля служебного помьзования оружия и патронов к нему, повлекшее его (их) утрату, если это не влечет за собой уголовную ответственность и $\mathrm{Ap}$.

В-четвертых, отмичается и порядок применения и снятия Аисциплинарных взысканий Аля размичных виАов государственной службы. Так, Ао применения Аисциплинарного взыскания преАставитель нанимателя Аолжен затребовать от служащего объяснение в письменной форме. В случае отказа Аать такое объяснение составмяется соответствующий акт. Отказ служащего от Аачи объяснения в письменной форме не яв-

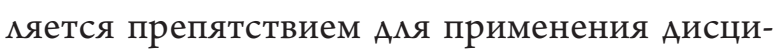
пиинарного взыскания. ПереА применением Аисциплинарного взыскания проводится служебная проверка.

А в ст. 50 Закона о службе в ОВА переА применением Аисциплинарного взыскания может быть проведена служебная проверка Аля установления всех обстоятельств проступка. Эта норма Аиспозитивная и буквально означает, что проверка может не проводиться.

B-пятых, отмичаются сроки наложения взысканий. Так, в отношении гражАанских служащих Аисципиинарное взыскание применяется непосреАственно после обнаружения Аисципиинарного проступка, но не позАнее одного месяиа со дня его обнаружения. А Аисциплинарное взыскание на сотруАника ОВА Аолжно быть наложено не позАнее чем через Аве неАели со Аня, когАа прямому руководителю (начальнику) стало известно о совершении Аисципиинарного проступка, а в случае провеАения служебной проверки или возбужАения уголовного Аела не позАнее чем через оАин месяц со Аня утвер-
жАения заключения по результатам ее или вынесения окончательного решения по уголовному Аелу. В указанные сроки не включаются периоды временной нетруАоспособности сотруАника, нахожАения его в отпуске или в командировке.

Аисциплинарное взыскание в отношении гражАанских служащих и служащих OBA не может быть применено позднее шести месяцев со Аня совершения Аисциплинарного проступка, а по резумьтатам проверки финансовохозяйственной Аеятемьности или ауАиторской проверки - позАнее Авух мет со Аня совершения Аисциплинарного проступка. В указанные сроки не включается время производства по уголовному Аелу.

Пункт 83 Аисциплинарного устава опреАеляет, что применение Аисципиинарного взыскания к военнослужащему, совершившему Аисципиинарный проступок, произвоАится в срок Ао 10 суток со Аня, когАа КоманАиру (начамьнику) стало известно о совершенном Аисциплинарном проступке (не считая времени на провеАение разбирательства, производство по уголовному Аеку или по Аелу об аАминистративном правонарушении, времени болезни военнослужащего, нахожАения его в командировке или отпуске, а также времени выполнения им боевой задачи), но Ао истечения срока Аавности привлечения военнослужащего к Аисциплинарной ответственности.

10-дневный срок применения взыскания прерывается на время: а) проведения разбирательства; б) производства по уголовному Аелу или по Аелу об аАминистративном правонарушении; в) болезни военнослужащего, нахожАения его в командировке или отпуске; г) выполнения военнослужащим боевой заАачи.

В ст. 28.8 Фелерамьного закона от 27 мая 1998 г. № 76-Ф3 «О статусе военнослужащих» установлен срок разбиратемьства. Он не может превышать 10 суток с момента, когАа команАиру стало известно о совершении военнослужащим или гражАанином, призванным на военные сборы, Аисципиинарного проступка. Таким образом, при отсутствии производства по угомовному Аему или по Аелу об аАминистративном 
правонарушении, бомезни военноскужащего, нахождения его в командировке или отпуске, выполнения военнослужащим боевой задачи максимахьный срок применения взыскания составцяет 20 суток с момента совершения Аисциплинарного проступка.

Военнослужащий не может быть привлечен к Аисциплинарной ответственности по истечеНии ОАНОГО ГОАа СО АНЯ СОвершеНия АИсциПАинарного проступка.

В-шестых, Аля гражАанских служащих установ ен специамьный порядок применения взысканий (замечание, выговор, предупреждение о неполном Аолжностном соответствии) за коррупционные правонарушения, отмичный от общего поряАка применения Аисциплинарных взысканий за совершение Аисциплинарного проступка (за неисполнение или неналмежащее исполнение служащим по его вине возложенных на него служебных обязанностей).

Ст. 59.3 Закона о гражАанской службе к Аанным правонарушениям относит несоблюАение гражАанским служащим ограничений и запретов, требований о предотвращении ими об урегулировании конфмикта интересов и неисполнение установленных обязанностей в цемях противодействия коррупции. (Ст. 59.3 была введена Фелеральным законом от 21 октября 2011 г. № 329-Ф3).

Порядок применения взысканий за коррупционные правонарушения, в отличие от поряАка применения и снятия Аисципминарного взыскания, имеет свои особенности. Так, например, применение взыскания за коррупционные правонарушения производится на основании Аоклада о результатах проверки, проведенной подразделением каАровой службы соответствующего государственного органа по профилактике коррупционных и иных правонарушений, а в случае, если доклаА о результатах проверки направ ялся в комиссию по урегулированию конфликтов интересов, - и на основании рекоменАации указанной комиссии. Взыскание за коррупционное правонарушение снимается По истечении оАного гоАа со Аня Применения взыскания. Если в течение этого года служа- щийся не привлекался к Аисциплинарной ответственности. Но законодатель не предусмотрел право преАставителя нанимателя снять взыскание за Аанные правонарушения Ао истечения опредеменного срока по собственной инициативе, по письменному заяв ению гражАанского скужащего ими по ходатайству его непосреАственного руководителя.

Фелеральным законом от 22 Аекабря 2014 г. № 431-ФЗ в Закон о службе в ОВА была введена анамогичная ст. 50.1 о коррупционных правонарушениях. Но при этом привлечение к ответственности осуществцяется на общих основаниях в отличии от поряАка, предусмотренного Законом о гражАанской службе.

В то же время ни Фелеральный закон от 27 мая 1998 г. № 76-Ф3 «О статусе военнослужащих», ни Аисципиинарный устав ВС РФ не акцентирует внимание на коррупционных Аисципиинарных проступках.

В-седьмых, В-седьмых, в отношении гражАанских служащих и служащих правоохранительной службы не установлен такой виА взыскания как Аисциплинарный арест. Аисциплинарный арест является крайней мерой Аисциплинарного возАействия и заключается в содержании военнослужащего или гражАанина, призванного на военные сборы, в условиях изомяции на гарнизонной мибо войсковой (корабельной) гауптвахте. Аисциплинарный арест применяется в искмючительных случаях и только за совершенный им грубый Аисциплинарный проступок. Если грубым Аисциплинарным проступком является аАминистративное правонарушение, то Аисциплинарный арест может быть применен только в том случае, когАа за такое аАминистративное правонарушение КоАП РФ предусмотрено аАминистративное наказание в виде аАминистративного ареста.

Аисциплинарный арест назначается на срок Ао 30 суток за оАин ими несколько грубых Аисциплинарных проступков. Если грубым Аисципиинарным проступком явмяется аАминистративное правонарушение, то срок Аисципиинарного ареста устанавмивается в пределах срока аАминистративного ареста. 
Аисциплинарный арест за грубый Аисципиинарный проступок, совершенный в периоА отбывания Аисциплинарного ареста не Аолжен превышать 45 суток.

Аисциплинарный арест назначается судьей гарнизонного военного суАа в порядке установленном Федеральным законом от 1 декабря 2006 г. «О суАопроизводстве по материалах о грубых Аисциплинарных проступках при применении к военнослужащим Аисциплинарного ареста и об исполнении Аисциплинарного ареста» (с изм.).

Порядок и условия привлечения служащих к материацьной ответственности также размичаются по виАам государственной скужбы.

Материальная ответственность госуаарственных служащих наступает за неправомерные Аействия (бездействие), в результате которого причинен материальный ущерб государству. Ответственность выражается в его возмещении в аАминистративном ПоряАКе или по суАу. Государственные гражАанские служащие несут ее в соответствии с главой 39 ТК РФ. В нем поА прямым Аействительным ущербом понимается реальное уменьшение наличного имущества наниматемя ими ухудшение состояния указанного имущества, а также необходимость Амя наниматемя произвести затраты мибо измишние выпиаты на приобретение или восстановмение имущества. Материальная ответственность исключается в случаях возникновения ущерба вслеАствие непреоАолимой силы, нормального хозяйственного риска, крайней необходимости ими необходимой обороны мибо неисполнения нанимателем обязанности по обеспечению наАмежащих условий Аля хранения имущества, вверенного служащему.

В ТК РФ установлены предель материальной ответственности. Так, за причиненный ущерб служащий несет материальную ответственность в пределах своего среАнего месячного заработка, в полном размере в случаях, преАусмотренных фелерацьными законами. Mameриальная ответственность в полном размере причиненного ущзерба возмагается на служащего в следующих случаях: 1) когАа на него возмо- жена материацьная ответственность в полном размере за ущерб, причиненный работодателю при исполнении работником трудовых обязанностей; 2) неАостачи ценностей, вверенных ему на основании специамьного письменного Аоговора ими полученных им по разовому Аокументу; 3 ) умышленного причинения ущерба; 4) причинения ущерба в состоянии алкогольного, наркотического или токсического опьянения; 5) причинения ущерба в резумьтате преступных Аействий служащего, установленных приговором суда и Ар. Материацьная ответственность в полном размере причиненного нанимателю ущерба может быть установлена служебным контрактом, заключаемым с руководителем организации, заместитемями руководитемя, гмавным бухгалтером. При совместном выполнении служащими отАельных видов работ, связанных с хранением, обработкой, продажей (отпуском), перевозкой, применением или иным использованием переданных им ценностей, когАа невозможно разграничить ответственность кажАого за причинение ущерба и заключить с ним Аоговор о возмещении ущерба в полном размере, может вводиться комлективная (бригадная) материальная ответственность. ТК РФ определяет порядок определения размера причиненного ущерба и его взыскания с виновных миц.

Распространение норм трудового законодательства, регулирующих материальную ответственность, на гражАанских служащих, на служащих правоохранительных органов связано с тем, что в служебном законодательстве отсутствует специальный нормативноправовой акт о материальной ответственности госуаарственных и муниципальных служащих. Законодательство о труде не распространяется на военнослужащих. Они несут материальную ответственность в соответствии с ФеАерацьным законом от 12 июмя 1999 г. «О материальной ответственности военноскужащих (с изм.).

В связи с этим напрашивается вопрос, почему законодатемь не установим аАминистративно-правовой порядок привлечения к материацьной ответственности служащих правоохранительных органов. ВеАь правоохранительная 
скужба близка к военизированной, выполняет особые функции - обеспечение безопасности, законности и правопорядка, борьба с преступностью, защита прав человека и гражАанина. Аанные особенности правоохранительной службы свидетельствуют о необходимости законодательной регламентации порядка привлечения к материальной ответственности скужащих правоохранительной службы нормами административного права.

Закон о материальной ответственности военнослужащих устанавливает основания и размеры материальной ответственности военнослужащих и гражАан, призванных на военные сборы, за ущерб, причиненный ими при исполнении обязанностей военной скужбы имуществу, находящемуся в федеральной собственности и закрепленному за воинскими частями, а также опредемяет порядок возмещения причиненного ущерба. Военноскужащие несут материальную ответственность только за причиненный по их вине реальный ущерб, т.е., если произошла утрата или повреждение имущества воинской части, расходы, которые воинская часть произвека либо должна произвести ААя восстановмения, приобретения утраченного или поврежАенного имущества, а также измишние Аенежные выплаты, произведенные воинской частью.

Военнослужащие, причинившие ущерб не при исполнении обязанностей военной скужбы, несут материальную ответственность в соответствии с гражАанским законодательством. Не Аопускается привлечение военноскужащих к материальной ответственности за ущерб, причиненный вслеАствие исполнения приказа командира (начальника), а также в результате правомерных действий, оправданного скужебного риска, Аействия непреодолимой силы.

Военнослужащие могут быть привлечены к материальной ответственности в течение трех мет со Аня обнаружения ущерба. Закон устанавливает Ава виАа этой ответственности - ограниченную и полную в зависимости от служебного положения военнослужащего, формы вины, размера ущерба и Аругих обстоятельств.
В законодательстве установлены большие различия в привлечении к административной ответственности гражданских служащих, по сравнению с военноскужащими и скужащими правоохранительной службы.

ГражАанские служащие за совершение аАминистративных правонарушений привлекаются к аАминистративной ответственности в соответствии с КоАП РФ. А военноскужащие и скужащие правоохранительной службы, имеющие специальные звания (органов внутренних Аел, уголовно-исполнительной системы, Государственной противопожарной службы, органов по контролю за оборотом наркотиков, таможенных органов), за совершение большинства правонарушений, обозначенных в КоАП РФ, привлекаются к ответственности в соответствии с нормативными правовыми актами, регламентирующими порядок прохожАения государственной службы и Аисциплинарными уставами (ст. 2.5 КоАп РФ).

Статьей 2.5 (ч. 2) КоАП РФ определен круг правонарушений, за совершение которых эти мица несут административную ответственность на общих с Аругими гражАанами основаниях. В перечень таких правонарушений вкмючены нарушения законодательства о выборах и референдумах, законодательства о размещении заказов на поставки товаров, выполнение работ, оказание услуг Аля нужА заказчиков, требований в области обеспечения санитарно-эпидемиологического благополучия насемения, соблюдения пожарной безопасности вне места службы, аАминистративные правонарушения в области налогов, сборов и финансов, некоторые Аругие правонарушения.

КАицам, совершившим перечисленные правонарушения, могут быть применены меры аАминистративного наказания, предусмотренные КоАП (за некоторыми искмючениями в виде аАминистративного ареста, не совместимого с несением военной службы, и штрафа, не применяемого к военнослужащим, проходящим службу по призыву, а также к курсантам военных образовательных учрежАений Ао заключения с ними контракта о прохождении военной 
службы). Предусмотрена возможность мишения военнослужащих водительских прав за нарушения Правил дорожного Авижения. К ним не применяется наказание в виде Аисквамификации.

В соответствии с ч. 4.1 ст. 27.3 КоАП об аАминистративном задержании военноскужащего или гражАанина, призванного на военные сборы, незамеАлительно уведомияется военная полиция Вооруженных Сил РФ или воинская часть, в которой задержанный проходит военную службу (военные сборы), а об аАминистративном задержании служащего правоохранительной службы - орган или учрежАение, в котором задержанный проходит службу.

Вместе с тем в соответствии со ст. 24.5 КоАП в случае, когАа административное правонарушение совершено военноскужащим, гражданином, призванным на военные сборы, или мицом, имеющим специальное звание, производство по делу после выяснения всех обстоятельств совершенного правонарушения подиежит прекращению (поАп. 1 ч. 1.1 ст. 29.9 КоАП) Аля привлечения Аанного Аица к Аисциплинарной ответственности. Исключение составцяют скучаи, когАа за такое правонарушение это мицо несет административную ответственность на общих основаниях, что предусмотрено в ч. 2 ст. 2.5 КоАП.

Согласно ст. 28.9 при наличии хотя бы оАного из обстоятельств, перечисленных в ст. 24.5 КоАП (отсутствие события аАминистративного правонарушения; отсутствие состава административного правонарушения; невменяемость физического мица, совершившего противоправные Аействия (бездействие); Аействия мица в состоянии крайней необходимости; изАание акта амнистии, если такой акт устраняет применение административного наказания; отмена закона, установившего административную ответственность; истечение сроков Аавности привлечения к аАминистративной ответственности; смерть физического лица, в отношении которого ведется производство по Аелу об аАминистративном правонарушении и Ар.), производство по Аелу об аАминистративном правонарушении подмежит прекращению.
Постановмение о прекращении произвоАства по Аелу об административном правонарушении по основанию, преАусмотренному ч. 2 ст. 24.5 КоАП, со всеми материалами дела в течение суток с момента вынесения постановления направляется в воинскую часть, орган или учрежАение по месту военной службы (скужбы) или месту прохожАения военных сборов Аица, совершившего административное правонарушение, Аля привлечения указанного мица к Аисциплинарной ответственности (ч. 2 ст. 28.9 КоАП).

Таким образом, составмение протокола об административном правонарушении ики иного Аокумента, предусмотренного ч. 4 ст. 28.1 КоАП, в отношении военноскужащего, означает возбужАение в отношении его дела об административном правонарушении, что преАполагает послеАующее применение соответствующих норм КоАП (выяснение всех обстоятельств Аела, прекращение Аела, направление постановмения о прекращении дела вместе с материалами в воинскую часть).

По данным Судебного Аепартамента при Верховном суде РФ за первое полугодие 2014 года было рассмотрено 3445 дел о привмечении военноскужащих к аАминистративной ответственности. В итоге, к административной ответственности было привлечено 2175 военнослужащих. Предупреждение было применено в отношении 8 из них, аАминистративный штраф был назначен 1839 мицам, конфискация - 5, мишение специального права - 316, а мишение права управления транспортным среАством - 692 военноскужащим ${ }^{[1]}$.

В результате принятия Федерального закона от 17 июмя 2009 г. № 160-ФЗ применение аАминистративного наказания в виде Аисква$\Lambda$ ификации стало возможно и в отношении гражАанских служащих. Так, на практике, не менее 50 процентов нарушений антимонопольного законодательства составцяют нарушения, совершаемые чиновниками. Аействующие санкции в виде аАминистративных штрафов не всега позволяют обеспечить эффективное соблюдение установценных за- 
претов. Аисквалификация Аля гражАанских скужащих была введена в связи с принятием, так называемого второго антимонопольного закона Аля борьбы с нарушениями антимонопольного законодательства, ущемляющими права преАприниматемей.

В ст. 3.11 КоАП РФ преАусматривается, что Аисквалификация закмючается в мишении физического мица права замещать Аолжности государственной гражАанской скужбы. Законодатель не уточняет, о каких именно Аолжностях гражАанской службы идет речь. Поэтому не обязательно, что это будет тот гражАанский скужащий, который обладает статусом Аолжностного Аица.

По инициативе Правительства в ст. 5.63 «Нарушение законодательства об организации предоставцения государственных и муниципальных ускуг» КоАП РФ были внесены изменения, предусматривающие Аисквалификацию Аля Аолжностных миц федеральных органов исполнительной власти в случае, если они ранее привлекались административному наказанию за нарушение законодательства о предоставмении государственных услуг. ОАновременно была изменена реАакция ст. 19.6.1 «Несоблюдение Аолжностными мицами органов госуАарственного контроля (наАзора) требований законоАательства о контроле (надзоре) $\gg$, в результате чего аАминистративное наказание в виде Аисквалификации было установлено за повторное нарушение Аолжностным Аицом органов исполнительной власти требований законодательства о контроле (наззоре).

Обращение к судебной статистике позволяет говорить, что Аисквалификация применяется крайне реАко. Так, за несоблюдение Аолжностными мицами органов государственного и муниципального контроля (наАзора) требований законодательства о государственном контроле (наАзоре) (ст. 19.6.1) в первом полугодии 2014 г. преАупрежАение получили 133 служащих, а штраф был наложен на 67 Аолжностных миц. Но, к сожалению, в Отчете о Аеятельности суАов общей юрисАикции по рассмотрению Аел об аАминистративных правонарушениях за указанный периоА не указано какое количество из них составцяли госуАарственные скужащие.

ОтАельной строкой в Отчете о Аеятельности СУАОв Общей юрисАИкции По рассмотрению Аел об административных правонарушениях указано количество гражданских служащих, привлеченных к аАминистративной ответственности по ст. 5.59 «Нарушение порядка рассмотрения обращений гражАан »: $183-$ федеральных государственных гражданских служащих (к 2 из них было применено преАупрежАение, а к 181 - штраф) и 105 государственных гражАанских служащих субъектов РФ (всем был назначен штраф).

В тоже время за нарушение законодательства об организации предоставления государственных услуг (ст. 5.63), за ограничение конкуренции органами вмасти, органами местного самоуправления (ст. 14.9), несоблюдение Аолжностными мицами органов государственного контромя (наззора) требований законодательства о государственном контроле (наАзоре) (ст. 19.6.1) ни оАин государственный скужащий не был подвергнут Аисквалификации за первое полугодие 2014 г. А именно эти статьи содержат те составы административных правонарушений, по которым, как преАставмяется, наиболее вероятно привлечение к ответственности гражАанских скужащих.

Возможно, причиной реАкого применения Аисквалификации может скужить и корпоративная солидарность чиновников. КогАа наА гражАанским служащим нависнет угроза применения к нему Аисквалификации, он приложит максимум усилий Аля того, чтобы улаАить возникшую проблему с Аолжностными мицами той же Федеральной антимонопольной скужбы, которые уполномочены возбужАать соответствующее производство по Аелу об аАминистративном правонарушении.

В Послании Презилента ФеАеральному Собранию 2012 г. ГАава государства последовательно поАтверАил свою Позицию. Говоря о необходимости кардинально повысить персонацьную ответственность, Президент РФ вновь 
заострил вопрос о временной Аисквалификации чиновников.

Необходимо сказать об исполнении этого вида наказания. Исполнение постановмения о Аисквалификации производится путем прекращения договора (контракта) с Аисквамифицированным мицом (ч. 2 ст. 32.11 КоАП РФ). Аисквалификация назначается на срок от шести месяцев Ао трех мет. Установцено, что Фелеральная налоговая служба ведет Реестр Аисквалифицированных миц. Поэтому необхоАимо осуществление контромя, направленного на недопущение поступления на гражАанскую

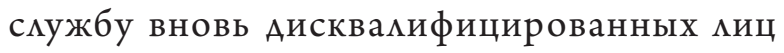
Ао истечения срока их аАминистративного наказания.

В СМИ много пишется о нарушениях чиновников. К Аействиям (решениям) госуАарственных служащих, которые могут быть обжалованы в суА, относятся комлегиальные и еАиноличные Аействия (решения), в том числе преАставление официальной информации, в результате которых: нарушены права и свободы гражАанина; созАаны препятствия к осуществиению гражАанином его прав и свобод; незаконно на гражАанина возцожена какая-

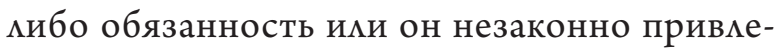
чен к какой-цибо ответственности.

В КоАП РФ есть статья 19.1, предусматривающая универсальный состав «Самоуправство». По ней может быть привлечен к аАминистративной ответственности Аюбой гражАанский служащий, а не только обладающий статусом Аолжностного мица ${ }^{[2]}$. Таким образом, аАминистративная ответственность за допускаемые гражАанскими служащими административные Аеликты наступает в реАких избирательных скучаях.

\section{БИБАИОГРАФИЯ}

1. Сводные статистические сведения о Аеятельности феАеральных судов общей юрисдикции и мировых судей за первое полугодие 2014 года: Отчет о Аеятельности судов общей юрисаикщии по рассмотрению дел об административных правонарушениях (форма № 1-AП): http://www. cdep.ru/index.php?id=79\&item=2361. 14.04.2015.

2. Гришковец А.А. Аисквалификация государственных гражАанских скужащих // ААминистративное и муниципаньное право.—2013.—№ 12.— С. 25

\section{REFERENCES (TRANSLITERATED)}

1. Svodnye statisticheskie svedeniya o deyatel'nosti federal'nykh sudov obshchei yurisdiktsii i mirovykh sudei za pervoe polugodie 2014 goda: Otchet o deyatel'nosti sudov obshchei yurisdiktsii po rassmotreniyu del ob administrativnykh pravonarusheniyakh (forma № 1-AP): http://www.cdep. ru/index.php?id=79\&item=2361. 14.04.2015.

2. Grishkovets A. A. Diskvalifikatsiya gosudarstvennykh grazhdanskikh sluzhashchikh // Administrativnoe i munitsipal'noe pravo. -2013.—№ 12.— S. 25 